\title{
Environmental Impacts of Bovine Meat Production
}

\author{
${ }^{1}$ Laboratory of animal and food resources National Agronomic Institute of Tunisia \\ ${ }^{2}$ Mateur Higher School of Agriculture of Mateur, Bizrte, Tunisia \\ ${ }^{3}$ Ministery of Agriculture. CRDA Ben Arous, Tunisia \\ ${ }^{4}$ Ministery of Agriculture, General Direction of Agricultural production, Tunisia \\ ${ }^{5}$ Ministery of Agriculture, Pasture and Livestock Office, Mateur, Tunisia
}

Takwa Aloui ${ }^{1}$, M'hamdi Naceur ${ }^{1 *}$, Bouraoui Rachid ${ }^{2}$, M'hamdi Hajer ${ }^{3}$, Haykel Hechlef $f^{4}$ and Mouna Hedhli ${ }^{5}$

Submission: November 05, 2018; Published: December 06, 2018

*Corresponding author: M'hamdi Naceur, Laboratory of animal and food resources National Agronomic Institute of Tunisia, Tunisia

\begin{abstract}
Climate change threatening the well-being of current and future generations. Livestock sector plays an important role in climate change. Beef and cattle milk production account for most of the emission. The objective of this article was to provide an overview of the bovine meat production environmental impact. Especially, the main greenhouse gases (GHG) emitted by this subsector, the main GHG emissions sources and some mitigation strategies. Methane $\mathrm{CH}_{4}$ (the greenhouse gas related to animal emissions), Nitrous oxide $\mathrm{N}_{2} \mathrm{O}$ (the most powerful greenhouse gas) and Carbon dioxide $\mathrm{CO}_{2}$ are the main GHG emitted by beef cattle. The main emission sources considered include enteric fermentation, manure management, nitrogen inputs, direct energy, inputs used within the farm. Levers for mitigation strategies include animal feeding, productivity and flock management, nitrogen fertilization, management of rejections, energy reduction and carbon storage.
\end{abstract}

Keywords: Beef; Production-greenhouse gases; Emissions-Methane-Nitrous; Oxide-Carbon dioxide

\section{Introduction}

Now a days global warming is the most dangerous environmental problem that human can faces it. It represents a threat to the living being. Most people are still unaware of global warming and do not consider it to be a big problem in years to come. What most people do not understand is that global warming is currently happening, and we are already experiencing some of its withering effects. It is and will severely affect ecosystems and disturb ecological balance. However, 97\% of climate scientists and researchers agree that humans have changed the Earth's atmosphere in dramatic ways over the past two centuries, resulting in global warming [1].

The mainly cause of global warming is the continuous rise in planet's temperature. And small changes in that temperature correspond to enormous changes in the environment [1,2] affirm that this rise in planet's temperature causes by increasing of greenhouse gases rate in atmosphere such as carbon dioxide $\mathrm{CO}_{2}$, methane $\mathrm{CH}_{4}$ and nitrous oxide $\mathrm{NO}_{2}$. Therefore more, Steinfeld et al (2006) state that three of the most important greenhouse gases; carbon dioxide $\left(\mathrm{CO}_{2}\right)$, methane $\left(\mathrm{CH}_{4}\right)$, and nitrous oxide $\left(\mathrm{N}_{2} \mathrm{O}\right)$, are emitted largely due to livestock activities. Also, according to the FAO report livestock production contributes to $18 \%$ of total anthropogenic greenhouse gases emissions.

In the other hand, in European Union livestock sector is major of agricultural economy and its land use. There is a different subsector and within each subsector a range of different production systems, we note a rise of intensification, larger farm units and more diversity of farming systems [3]. Andrien [3] note that according to the CAPRI model calculations agriculture sector emit $49 \%$ of total GHG emissions, $21 \%$ from energy sector, $2 \%$ from industrial sector and $29 \%$ from land use and land use change. About the livestock sector, European livestock production emit a total GHG fluxes of 661 Mio tons of CO2-eq, which is distributed as follows: $29 \%$ are coming from beef production, $29 \%$ from cow milk production, $25 \%$ from pork production, $17 \%$ are coming from all other animal products.

Therefor more, Pelletier et Tyedmers report that by conjunction, in 2050 direct GHG emissions from meat, milk and egg production are projected to increase by $39 \%$ over the year 2000. So, meat beef production one of the major sub-sectors of livestock sector that contributes to GHG emissions. We focus in this study on beef production GHG emissions and mitigation strategy applied to mitigate this environmental impact.

Environmental Impact of Meat Production: Greenhouse Gases Emissions

\section{Overview of the Meat Production Sector}

According to Steinfeld [4] because of the increase of the population and the rise of the standard of living between 2000 
and 2050 the demand of meat will split of 229 million tons per quantity of beef is produced by the USA in 2012. In the other hand year to 465 million tons per year. According to Table 1 the largest beef cattle is one of the most species which emit GHG (Figure 1).

Table 1: Production and consumption of beef worldwide in 2012 (La viande.fr).

\begin{tabular}{|c|c|c|c|}
\hline Country (2012) & Production (thousands of tons) & Consumption (thousands of tons) & Consumption (kg eqc/inhabitant) \\
\hline UE at 27 & 7760 & 7760 & 15 \\
\hline USA & 11855 & 11744 & 37 \\
\hline Brazil & 8669 & 7045 & 59 \\
\hline Argentina & 2620 & 2458 & 33 \\
\hline Australia & 2152 & 745 & 25 \\
\hline New Zealand & 615 & 110 & 17 \\
\hline Russia & 1380 & 2395 & 4 \\
\hline China & 5540 & 5600 & 2 \\
\hline India & 3460 & 2050 & \\
\hline
\end{tabular}

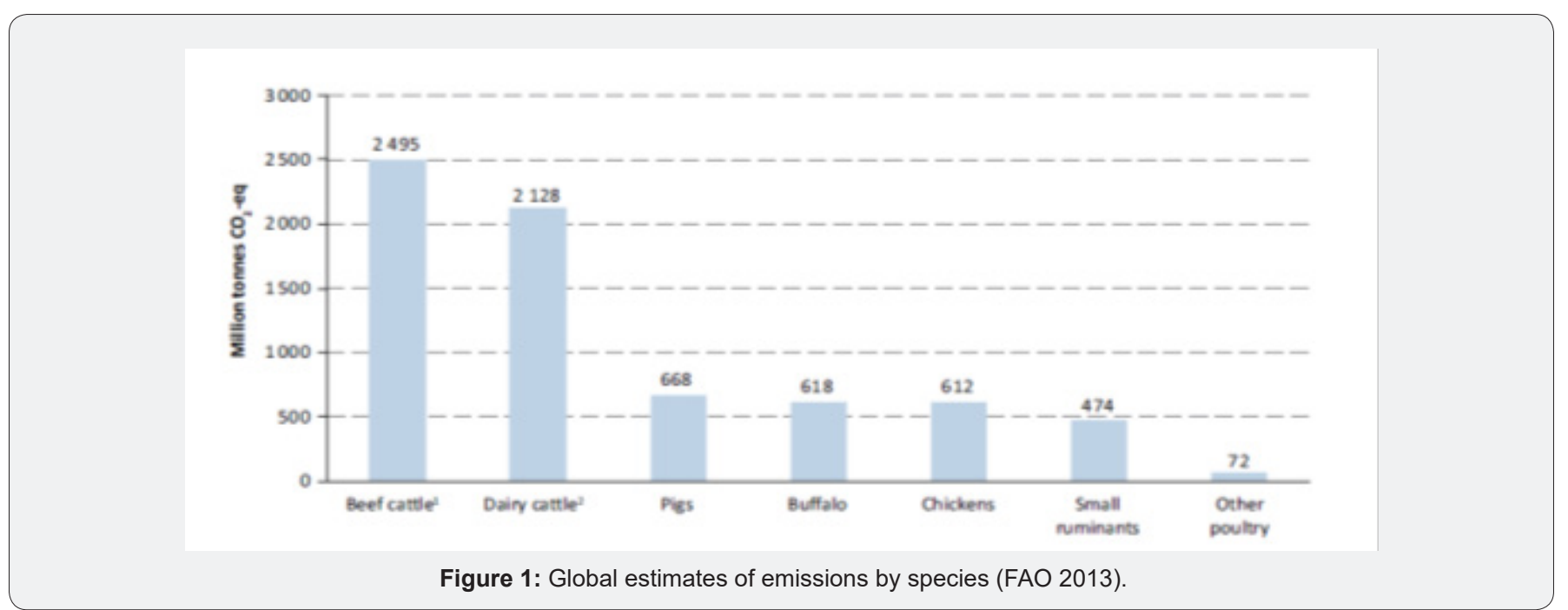

\section{The main Gases emitted by Cattle}

The greenhouse gases comprise only about $1 \%$ of the total gases in the earth's atmosphere. The predominant gases are oxygen (21\% of the total) and nitrogen (78\% of the total). The primary greenhouse gases are carbon dioxide, methane, nitrous oxide, ozone and water vapor. These gases trap infrared energy that contributes to higher atmospheric temperatures. It is important to remember that carbon dioxide, methane and nitrous oxide are continuously emitted and removed from the atmosphere by natural processes. In addition to these natural processes, anthropogenic activities also cause emissions of some of these gases [5].

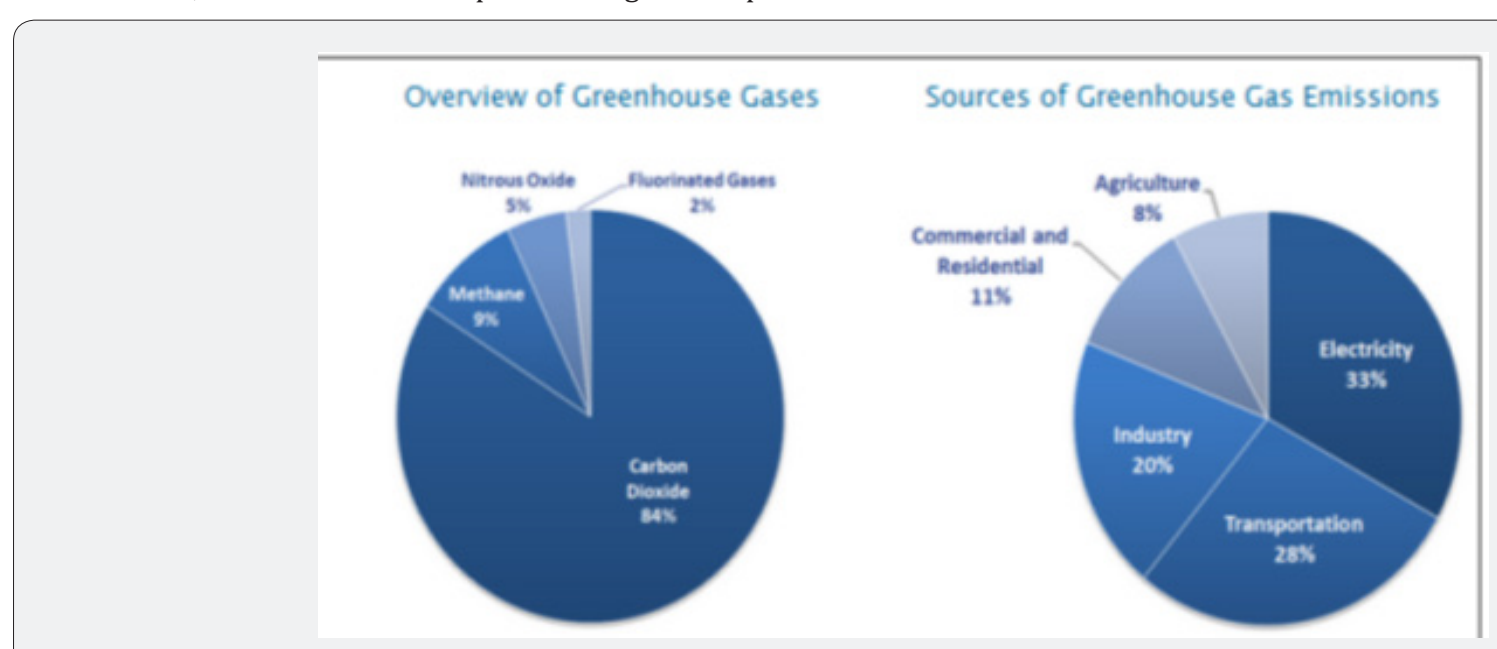

Figure 2: Overview of greenhouse gas and sources of greenhouse gas emissions in U.S in 2013. 
There are mainly $\mathrm{CO}_{2}, \mathrm{CH}_{4}$ and $\mathrm{NO}_{2}$. But there are also other gases such as fluorinated gases (CFC, HFC, PFC, SF6) that do not concern the agricultural field. Each gas is characterized by their global warming potential, it is the cumulative heating forcing over a defined period. It is measured in relation to $\mathrm{CO}_{2}$ and is expressed in $\mathrm{kg} \mathrm{CO}_{2}$ equivalent [6]. The main gases emitted by beef cattle are: Methane $\mathrm{CH}_{4}$, Nitrous oxide $\mathrm{N}_{2} \mathrm{O}$ and Carbon dioxide $\mathrm{CO}_{2}$. As an example, Figure 2 shows an overview of greenhouse gases and sources of greenhouses gas emissions in US in 2013. This figure is from the Environmental Protection Agency website characterizes US greenhouse gas production. According to Figure 2: Methane represents 9\%, Nitrous oxide represents $2 \%$ and Carbon dioxide represents $84 \%$ of total US greenhouse gases. While, agriculture is responsible for $8 \%$ of the total US greenhouse gas emissions.

\section{Methane: $\mathrm{CH}_{3}$}

Methane is the greenhouse gas related to animal emissions [5]. Their warming potential is $25 \mathrm{~kg} \mathrm{CO}_{2} / \mathrm{Kg}$ of $\mathrm{CH}_{4}$. The plant diet of cows and other ruminants is high in cellulose, which cannot be digested by the ruminant itself. However, ruminants have a symbiotic relationship with colonies of microorganisms, called methanogens, which live in their gut and break down the cellulose into carbohydrates. These carbohydrates provide both the microbial community and the ruminant with an energy source. Methane is produced as a by-product of this process. Machen \& Mccollum [7] says that methane is a loss of dietary energy during digestion by microorganisms in the rumen.

\section{Nitrous oxide: $\mathrm{NO}_{2}$}

Nitrous oxide warming potential: $298 \mathrm{~kg} \mathrm{CO} / \mathrm{kg}$ of $\mathrm{NO}_{2}$. Nitrous oxide is a very sensitive greenhouse, it has a 296 times higher impact than $\mathrm{CO}_{2}$. One of important sources of $\mathrm{N}_{2} \mathrm{O}$ emissions is agricultural activities such as: The use of nitrate fertilizers, livestock production, and manure management. $\mathrm{N}_{2} \mathrm{O}$ is generated as an intermediate product or by-product of nitrification and denitrification processes. Their emission is very complex [8]. $\mathrm{NO}_{2}$ issues from nitrogen fertilizers (organic manures or inorganic fertilizers) or by manure storages and by deposition by grazing animals $[9,10] .50 \%$ of $\mathrm{NO}_{2}$ emissions is form animal agriculture [11]. The nitrogen excreted more in the urine whereas the nitrogen excreted in the dung is constant $[12,13]$.

\section{Carbone Dioxide: $\mathrm{CO}_{2}$}

Carbone dioxide $\mathrm{CO}_{2}$ has a lower warming potential then $\mathrm{CH}_{4}$ and $\mathrm{NO}_{2}$, but it has the most emitted gas especially from industrial sector. The use of fossil fuel is the most important emissions source of $\mathrm{CO}_{2}$, it can be also emitted by from land use, degradation of soil [14].

\section{Sources of GHG emissions from Bovine Meat}

\section{Production}

Dollé [5] have defined 5 mainly sources of emissions: a. Enteric fermentation: $\mathrm{CH}_{4}$ emissions from animal biological activity of cattle: Enteric fermentation is a process that characterizes ruminants. It occurs at the rumen level. It produces methane as a byproduct of a microbial fermentation of carbohydrates into simple molecules [15].

b. Manure management: $\mathrm{CH}_{4}$ and $\mathrm{NO}_{2}$ emission from the management of rejections (pasture, building, storage).

c. Manure contains two chemicals components: Organic matter converted to $\mathrm{CH}_{4}$ by anaerobic decomposition, mostly when manure is managed in liquid form, Nitrogen leads to nitrous oxide emissions by indirect transformation of nitrogen released in the atmosphere to ammonia $\mathrm{NH}_{3}$ and then to $\mathrm{N}_{2} \mathrm{O}$.

d. Nitrogen inputs: $\mathrm{NO}_{2}$ emission resulting from the nitrification and denitrification phenomena of direct nitrogen inputs through organic and mineral fertilization and indirect nitrogen inputs by nitrate leaching and ammonia volatilization.

e. Direct energy: $\mathrm{CO}_{2}$ emission from fossil fuels consumed on the farm (electricity and fuel).

f. Inputs: $\mathrm{CO}_{2}$ emission from transport of cattle feed, $\mathrm{NO}_{2}$ emission from fertilizer manufacturing.

Table 2: Emission source of GHG emitted by beef.

\begin{tabular}{|c|c|}
\hline Emission Source & Compounds \\
\hline Use of fertilizers (pastures and feed production) & $\mathrm{N}_{2} \mathrm{O}, \mathrm{NH}_{3}$ \\
\hline Manufacturing of fertilizers & $\mathrm{CO}_{2}, \mathrm{~N}_{2} \mathrm{O}$ \\
\hline $\begin{array}{c}\text { Land-use change due to grasslands expansion/ } \\
\text { cropland expansion for feed production }\end{array}$ & $\mathrm{CO}_{2}$ \\
\hline On-farm energy use & $\mathrm{CO}_{2}$ \\
\hline Enteric fermentation & $\mathrm{CH}_{4}$ \\
\hline Manure deposition by grazing animals & $\mathrm{NH}_{3}, \mathrm{~N}_{2} \mathrm{O}, \mathrm{CH}_{4}$ \\
\hline Indirect N20 from leaching and runoff & $\mathrm{N}_{2} \mathrm{O}$ \\
\hline Indirect N20 from deposition of NH3 & $\mathrm{N}_{2} \mathrm{O}$ \\
\hline Transport of animal products & $\mathrm{CO}_{2}$ \\
\hline
\end{tabular}

Therefore more, Andrian cited different emissions sources of beef which are illustrated in Table 2: Andrian considered $\mathrm{CH} 4$ from enteric fermentation is the important GHG source. While Gerber his model GLEAM (Global Livestock Environmental Assessment) ranked the sources of GHG emissions as shown in Table 3

a. The greenhouse gases emissions variation factors

b. Rumen activity and Animal feed

c. Rumen activity

The rumen is home to millions of microorganisms that digest food into co-products. Methane production in the rumen is related to the size of the protozoa. If the size of protozoa increases methane production also increases. It is also related to the percentage of hydrogen used to make methane [16]. 
Table 3: Sources of GHG emissions considered ont the GLEAM model (FAO 2013).

\begin{tabular}{|c|c|c|}
\hline Supply chain & Activity & GHG \\
\hline \multirow{3}{*}{ Upstream } & \multirow[b]{2}{*}{ Feed production } & 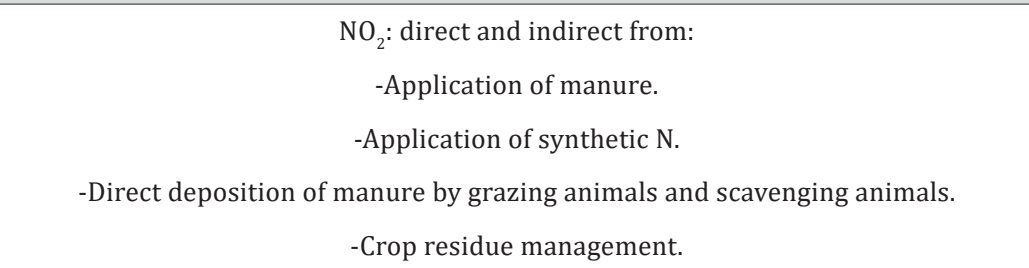 \\
\hline & & $\begin{array}{c}\qquad \mathrm{CO}_{2}, \mathrm{NO}_{2}, \mathrm{CH}_{4} \text { : } \\
\text {-Energy use in field operations. } \\
\text { - Energy use in feed transport and processing. } \\
\text {-Fertilizer manufacture. } \\
\text {-Feed blending. } \\
\text {-Production of non-crop feedstuff. } \\
\text {-Land use change related to soybean cultivation. }\end{array}$ \\
\hline & Non-feed production & $\mathbf{C O}_{2}$ : -Embedded energy related to manufacture of on-farm buildings and equipment. \\
\hline Animal production unit & Livestock production & $\begin{array}{c}\mathrm{CH}_{4}: \\
\text {-Enteric fermentation. -Manure management. } \\
\mathrm{NO}_{2}: \text {-Direct and indirect } \mathrm{NO}_{2} \text { from manure management. } \\
\mathbf{C O}_{2}: \text {-Direct on-farm energy use for livestock (ventilation, heating.) }\end{array}$ \\
\hline Downstream & Post farmgate & $\begin{array}{l}\qquad \mathbf{C O}_{2}, \mathbf{C H}_{4}, \mathbf{H F C s :} \\
\text {-Transport of live animals and products to slaughter and processing plant. } \\
\text {-Transport of processes products to retail point. } \\
\text {-Refrigeration during transport and processing. } \\
\text {-Primary processing of meat into carcasses. } \\
\text {-Manufacture of packaging. }\end{array}$ \\
\hline
\end{tabular}

\section{Animal feed}

Fibrous and poorly digestible diets cause an increase in $\mathrm{CH}_{4}$. In the other hand According to Machen et Mccollum diet influences the amount of methane. Cattle that consuming stem forage (high fiber) emit more methane then cattle that consuming concentrate (low fiber). They add that when highly available carbohydrates are fed at limited intakes, high fractional methane losses occur. At high intakes of highly digestible diets, low fractional methane losses occur.

\section{Productivity and Herd Management}

There is a relationship between productivity and GHG emissions intensity, when productivity and yields increase GHG emissions intensity decreases. According to Gerber poorer animal husbandry, lower slaughter weights and higher age at slaughter leading to higher GHG emissions. An increase in productivity without an excessive reliance on inputs that allows for an increase in the average daily gain, this leads to a reduction in the fattening time, and consequently a reduction in GHGs emissions associated with production. Guickshank assert that a good herd management: an adequate diet, a good reform of unproductive animals, an effective health management capacity to adapt to environmental changes, leads to a reduction of 2 to $5 \%$ of GHGs emitted by cattle farming.

\section{Carbon Storage/Restorage}

Soil change is reflected in a change of carbon flux in the soil, it is carbon storage and restorage. This can lead to GHG emissions of carbon sequestration. Any conversion of a forest or grassland into a crop induces GHG emissions (from 4 to 6 tonnes of $\mathrm{CO}_{2}$ / ha / year). Conversely, any conversion from a crop to a grassland induces sequestration of carbon in soils (from 0.84 to 2.75 tonnes $\mathrm{CO}_{2}$ / ha / year) [17]. According to Table, soil change from crop to grassland is better than soil change from grassland to crop because it mitigates $\mathrm{CO}_{2}$ emission and capture $\mathrm{CO}_{2}$.

\section{Nitrogen Fertilization}

Proper nitrogen management can reduce $90 \%$ of $\mathrm{CO}_{2}$ emissions [18]. Much of the nitrogen management is evident in the management of $\mathrm{N}$ input at the farm level. Moderate nitrogen fertilization reduces the purchases of synthesized fertilizers and consequently reduces carbonic gases emissions associated with their manufacture and transport (5.3 to $6.1 \mathrm{~kg}$ of $\mathrm{CO}_{2} / \mathrm{kg}$ of nitrogen).

\section{Energy Consumption}

Energy consumption within a farm is the major factor for $\mathrm{CO}_{2}$ emission. Dollé assert that the consumption of fuel and electricity causes the direct emission of $\mathrm{CO}_{2}$. So, any reduction 
in energy consumption will reduce the $\mathrm{CO}_{2}$ emission (mitigation strategies of energy consumption are more detailed in the third party).

\section{Mitigation Strategies}

Technologies and practices that help reduce emissions exist but are not widely used. Their adoption and use by the bulk of the world's producers can result in significant reductions in emissions. Dollé summarize action levers that can reduce GHG emissions from cattle (Table 4) it's through means that act on Animal feed, productivity and herd management, nitrogen fertilization and manure management, reduction of energy consumption and carbon storage. Table 5 shows this means and their effect on $\mathrm{CH}_{4}, \mathrm{NO}_{2}$ and $\mathrm{CO}_{2}$ emissions.

Table 4: Impact associated to soil change between crop and grassland Arrouays et al. (2002).

\begin{tabular}{|c|c|c|}
\hline Soil Conversion & Average Annual Additional Flow T C/ha/year & $\mathrm{CO}_{2}$ Equivalences Emitted or Captured $\left(\mathrm{T} \mathrm{CO}_{2}\right.$ eq/ha/an $)$ \\
\hline Crop $\boldsymbol{\Downarrow}$ grassland & Carbon storage $0.49+-0.26$ & $\mathrm{CO}_{2}$ capture 0.84 to 2.75 \\
\hline Grassland $\mathbf{\nabla}$ crop & Carbon Destorage $-0.95+-0.3$ & $\mathrm{CO}_{2}$ emission 2.4 to 4.6 \\
\hline
\end{tabular}

Table 5: Potential effects of the main levers of action on GHG emissions.

\begin{tabular}{|c|c|c|c|c|}
\hline Action Lever & $\mathrm{CH}_{4}$ & $\mathrm{NO}_{2}$ & $\mathrm{CO}_{2}$ & Potential Effect on Reducing the Net Carbon Foot Print of Products \\
\hline \multicolumn{5}{|l|}{ Animal Feed } \\
\hline Increase in the Share of Concentrates & $\downarrow$ & - & $\downarrow$ & 0 to $5 \%$ \\
\hline Fat Intake & $\downarrow$ & - & - & 3 to $7 \%$ \\
\hline Food Additives & $\downarrow$ & $\downarrow$ & - & $?$ \\
\hline $\begin{array}{l}\text { Optimization of the nitrogen content of } \\
\text { the Ration }\end{array}$ & - & $\downarrow$ & $\downarrow$ & $2 \%$ \\
\hline $\begin{array}{c}\text { Replacement of Soybean Meal with } \\
\text { Rapeseed Meal }\end{array}$ & - & - & $\downarrow$ & 3 to $7 \%$ \\
\hline Protein Autonomy & - & - & $\downarrow$ & 2 to $5 \%$ \\
\hline \multicolumn{5}{|l|}{ Productivity and herd Management } \\
\hline Productivity & $\downarrow$ & $\downarrow$ & $\downarrow \uparrow$ & -5 to $10 \%$ \\
\hline Renewal & $\downarrow$ & $\downarrow$ & $\downarrow$ & 0 to $5 \%$ \\
\hline Health optimization & $\downarrow$ & $\downarrow$ & $\downarrow$ & 2 to $5 \%$ \\
\hline Genetic Improvement & $\downarrow$ & $\downarrow$ & $\downarrow$ & 2 to $10 \%$ \\
\hline \multicolumn{5}{|l|}{ Nitrogen Fertilization } \\
\hline Reduction of Nitrogen Intake & - & $\downarrow$ & $\downarrow$ & 2 to $5 \%$ \\
\hline Introduction of legumes & - & $\downarrow$ & $\downarrow$ & 2 to $5 \%$ \\
\hline Nitrification Inhibitor & - & $\downarrow$ & $\downarrow$ & 0 to $5 \%$ \\
\hline \multicolumn{5}{|l|}{ Manure management } \\
\hline Optimization of pasture & $\downarrow$ & $\downarrow$ & - & 3 to $5 \%$ \\
\hline Optimum recovery of manure & - & $\downarrow$ & $\downarrow$ & 3 to $5 \%$ \\
\hline Methanation & $\downarrow$ & $\downarrow$ & $\downarrow$ & 5 to $7 \%$ \\
\hline \multicolumn{5}{|l|}{ Reduction of energy consumption } \\
\hline Electricity & - & - & $\downarrow$ & $<1 \%$ \\
\hline Oil & - & - & $\downarrow$ & 1 to $2 \%$ \\
\hline \multicolumn{5}{|l|}{ Carbon storage } \\
\hline $\begin{array}{l}\text { Increase the proportion of permanent } \\
\text { grasslands }\end{array}$ & - & - & $\downarrow$ & 3 to $10 \%$ \\
\hline Implement hedges & - & - & $\downarrow$ & 3 to $10 \%$ \\
\hline
\end{tabular}

\section{Mitigation strategy of $\mathrm{CH}_{4}$ emissions}

Focusing on animal feed (Table 4), we can use additives to limit enteric fermentation [19]. Or changing animal diet for example changing grass to maize can reduce methane from enteric fermentation [20]. Also, increase the part of concentrate in the ration, which replaces cellulose by starch, so it can reduce enteric methane. To reduce the production of methane in the rumen we can decrease the population of the protozoa by the ingestion of rations very rich in cereals. Or redirect the hydrogen used in the manufacture of methane in other biochemical pathways such as the sulphate or nitrate reductant route. Similarly, polyunsaturated fatty acids represent hydrogen sinks (capture hydrogen) so they try to reduce methagenesis. 
Concerning mitigation strategy applied to reduce methane and other GHG emissions from manure management we can site:

a. Composting, by aerating and ventilating stored manure, this decrease $\mathrm{CH}_{4}$ emission but increase $\mathrm{NO}_{2}$ emission from manure [21].

b. Excessive use of straw in litter can reduce GHG emission from manure [22].

c. -Manure compacting and coverage by plastic sheeting reduce $\mathrm{CH} 4$ but may increase $\mathrm{NO}_{2}$ according to climatological conditions [23].

In the other hand, according to Weske [24] more lactations per cow, less enteric methane emission. Because without producing milk there is more GHG emissions.

\section{Mitigation strategy of $\mathrm{NO}_{2}$ emissions}

As example of mitigation strategy of $\mathrm{NO}_{2}$ emissions from agriculture soil is nitrification inhibitors which can reduce roughly $30 \%$ of $\mathrm{NO}_{2}$ emission from soil [25]. Nitrification inhibitors can reduce losses by leaching and consequently reduce emissions, by slowing the production of nitrate nitrogen resulting from the transformation of the ammoniacal nitrogen of pissats and manure. This reduction can reach 60 to $68 \%$ of GHG emissions. This strategy is very much studied in New Zealand [26]. According to Soussana [27] reducing grazing intensity or overgrazing, reduce both $\mathrm{NO}_{2}$ emissions and soil organic carbon.

In the other hand, the division of ploughing grassland in several times per year instead of ploughing permanent grassland can reduce $\mathrm{NO}_{2}$ emissions from the soil. Or reducing ploughing area by leaving areas un-ploughed and sowing new seed under a no-till system [28]. According to Wulf [29] most effective way to reduce $\mathrm{NO}_{2}$ and $\mathrm{CH}_{4}$ both emissions from manure management is trail hose application in combination with immediate shallow, but that can increase $\mathrm{NH}_{3}$ emissions. Therefore more, the use of cropped crops, such as energy crops as buffer strips along open streams in order to mitigate nutrient leaching, so reducing $\mathrm{NO}_{2}$ in the atmosphere [30-32]. Focusing on manure biosolid management strategies such a: compacting and coverage, increasing straw content for composting, covering manure storage, no manure application in autuum, mitigates both $\mathrm{NO}_{2}$ and $\mathrm{CH}_{4}$ emissions gases. Also, the use of legumes reduces $\mathrm{NO}_{2}$ emissions, thanks to symbiotic fixation that dos nit emits GHGs.

\section{Mitigation strategy of $\mathrm{CO}_{2}$ emissions}

There are two main levels of $\mathrm{CO}_{2}$ mitigation strategies:

\section{a. Carbon storage}

Extensification can reduce $\mathrm{CO}_{2}$ emissions from soil by turning grassland into a carbon sink instead of a source. So, increase the proportion of permanent grassland. Implementation of hedges.

\section{b. Energy use}

Practice grazing instead of the installation of cultures has end of underestimate the consumption of fuel for harvesting, distribution of forage, spreading of droppings, reduce $\mathrm{CO}_{2}$ emissions from fuel use [33-35]. On the other hand, checking the tractors, good economic driving, reducing transport, simplifying farming practices..., can significantly reduce $\mathrm{CO}_{2}$ emission from energy use [5].

\section{Conclusion}

Methane $\mathrm{CH}_{4}$, Nitrous oxide $\mathrm{NO}_{2}$ and Carbone dioxide $\mathrm{CO}_{2}$ are the main GHGs emitted by beef cattle. $\mathrm{NO}_{2}$ is the most powerful GHG, which retains more heat than $\mathrm{CH}_{4}$ and $\mathrm{CO}_{2}$. Enteric fermentation, manure management, energy use and nitrogen inputs are the main GES emissions sources from bovine meat sector. Cattle is the agriculture sector that emits the most GHGs. So the aim is not only to encourage and support research and GHG abatement strategies, but also to popularize and raise awareness among all members of agricultural sector, especially producers, in order to highlight the seriousness of this situation, to find viable and achievable solutions.

More communication with farmers is needed, new policies and investments that facilitate the use of mitigation solutions. Meat production increases as demand increases. Therefore, adequate strategies are needed to limit GHG emissions while guaranteeing food safety, the state of the animal and avoiding any undesirable effects. We must strive for sustainable agriculture that preserves our natural and environmental resources.

\section{References}

1. Umair S (2015) Global Warming: Causes, Effects and Solutions. Durreesamin Journal 1: 4.

2. Holli R (2007) Global warming. Earth observatory. NASA.

3. Adrian L, Tom W, Francesco NT, Suvi M (2010) Evaluation of the livestock sector's contribution to the EU greenhouse gas emissions (GGELS)-Final report. Joint research centre-European commission.

4. Steinfeld H, Gerber P, Wassenaar T, Castel V, De Haan C (2006) Livestock's Long Shadow: Environmental Issues and Options. Food and Agriculture Organization of the United Nations.

5. Chase LE (2006) How much methane de cows emit? Department of animal science. Cornell University, New York, USA.

6. Dollé JB, Agabriel J, Peyraud L, Faverdin P, Manneville V, et al. (2011) Les gaz à effet de serre en élevage bovin : Evaluation et leviers d'action. INRA Prod Anim 24 (5): 415-432.

7. Machen R, Mccollum T (2016) Relationship Between Production System and Methane Loss by Beef Cattle. Environmental protection agency website. Texas A\&M AgriLife Extension Service. ASWeb-128.

8. Koki M, Sakae T, Ryosuke Sh, Takashi O, Dai H, et al. (2010) Source of Nitrous Oxide Emissions during the Cow Manure Composting Process as Revealed by Isotopomer Analysis of and amoA Abundance in Betaproteobacterial Ammonia-Oxidizing Bacteria. Applied and Environmental Microbiology. American Society for Microbiology. 76(5): 1555-15562.

9. Whalen SC, Phillips RL, Fischer EN (2000) Nitrous oxide emission from an agricultural field fertilized with liquid lagoonal swine effluent. Global Biogeochemical Cycles, 14: 545-558.

10. Crosson P, Shalloo L, O’Brien D, Lanigan GJ, Foley PA, et al. (2011) A review of whole farm systems models of greenhouse gas emissions from beef and dairy cattle production systems. Animal Feed Science and Technology, 166(167): 29-45. 
11. Klein de CAM, Eckard RJ (2008) Targeted technologies for nitrous oxide abatement from animal agriculture. Australian Journal of Experimental Agriculture, 48: 14-20.

12. Castillo AR, Kebreab E, Beever DE, France J (2000) A review of efficiency of nitrogen utilization in lactating dairy cows and its relationship with environmental pollution. Journal of Animal and Feed Sciences, 9: 1-32.

13. Eckard RJ, Chapman DF, White RE (2007) Nitrogen balances in temperate perennial grass and clover dairy pastures in south-eastern Australia. Australian Journal of Agriculture Research, 58: 1167-1173.

14. EPA (2017) Environmental Protection Agency. Global Greenhouse Gas emissions.

15. Gerber PJ, Steinfeld H, Henderson B, Mottet A, Opio C, et al. (2013) Tackling climate change through livestock - A global assessment of emissions and mitigation opportunities. Food and Agriculture Organization of the United Nations (FAO), Rome, Italy.

16. Dordeau M, Martin C, Eugene M, Popova M, Mirgani DP (2011) Leviers d'action pour réduire la production de méthane entérique par les ruminants. INRA Prod Anim 24(5): 461-474.

17. Arrouays D, Balesdent J, Germon JC, Jayet PA, Soussana JF, et al. (2002) Contribution à la lutte contre l'effet de serre. Stocker du carbone dans les sols agricoles de France? Expertise scientifique collective, INRA, synthèse, p. 36.

18. De Klein CAM, Eckard RJ (2008) Targeted technologies for nitrous oxide abatement from animal agriculture. Austr J Exp Agric 48 : 14-20.

19. Clemens J (2001) Greenhouse gases from animal husbandry: mitigation options. Nurient Cycling in Agroecosystems 60:287-300.

20. Kuikman PJ, Oudendag DA, Smit KW, vander Hoek (2003) ROB maatregelen in de landbouw en vermindering van emissies van broeikasgassen. Wageningen, Alterra, pp. 142.

21. Pattey E, Trzcinski MK, Desjardins RL (2005) Quantifying the reduction of greenhouse gas emissions as a result of composting dairy and beef cattle manure. Nutrient cycling in agroecosystems 72(2): 173-187.

22. Sommer SG, Møller HB (2000) Emission of greenhouse gases during composting - effect of straw content. Journal of Agricultural Science 134: 327-335.

23. Chadwick DR (2005) Emissions of ammonia, nitrous oxide and methane from cattle manure heaps: effect of compaction and covering. Atmospheric Environment 39: 787-799.
24. Weske A (2006) Mitigation of greenhouse gas emission in European conventional and organic dairy farming Agriculture, Ecosystems and Environment 112: 221-232.

25. IPCC (2006) IPCC Guidelines for National Greenhouse Gas Inventories. Intergovernmental panel on climate change. Nat. Greenhouse Gas Inv Ref Manual, p. 4.

26. Monaghan RM, Hedley MJ, Di HJ, McDowell RW, Cameron KC, et al. (2007) Nutrient management in New Zeland pastures. Recent developements and future issues. NZ J Agric Res 50 : 181-201.

27. Soussana JF (2001) Sources et puits de gaz à effet de serre (CO2, CH4, N20) en prairie pâturée et stratégies de réduction. Rapport final, Apr 2001 INRA.

28. Vellinga V, van den Pol-van Dasselaar, Kuikman PJ (2004) The impact of grassland ploughing on $\mathrm{CO}_{2}$ and $\mathrm{N}_{2} \mathrm{O}$ emissions in the Netherlands. Nutrient Cycling in Agroecosystems 70: 33-45.

29. Wulf S, Meting M, Clemens J (2002) Application Technique and Slurry Co-Fermentation Effects on Ammonia, Nitrous Oxide, and Methane Emissions after Spreading. Journal of Environmental Quality. 31: 17951801.

30. Borjesson P (1999) Environmental effects of energy crop cultivation in Sweden-I: Identification and quantification. Biomass-and-Bioenergy 16(2): 137-154.

31. Cruickshank G, Thomson B, Muir P (2009) Effect of management change on methane output within a sheep flock. Proc NZ Soc Anim Prod $69: 170-173$.

32. FAO (2006) Livestock's long shadow - environmental issues and options, Food and Agriculture Organization of the United Nations.

33. Alterra report (2003) In: Proceedings of the 3rd International Methane and Nitrous Oxide Mitigation Conference. Beijing, pp. 415-422.

34. Oenema O, Velthof GL, Kuikman PJ (2001) Technical and policy aspects of strategies to decrease greenhouse gas emissions from agriculture. Nutrient Cycling in Agroecosystems 60: 301-315.

35. Pelletier N, et Tyedmers P (2010) Forecasting potential global environmental costs of livestock production 2000-2050. Proceedings of the National Academy of Sciences of the United States of America, 107(43): 18371-18374.

Your next submission with Juniper Publishers
will reach you the below assets
- Quality Editorial service
- Swift Peer Review
- Reprints availability
- E-prints Service
- Manuscript Podcast for convenient understanding
- Global attainment for your research
- Manuscript accessibility in different formats
( Pdf, E-pub, Full Text, Audio)
- Unceasing customer service
Track the below URL for one-step submission
https://juniperpublishers.com/online-submission.php

